\title{
På sporet af den nye medietid Lyde og mislyde i 1920'ernes folkebiblioteker
}

\author{
Af Martin Dyrbye
}

\begin{abstract}
Abstrakt
Formålet med denne artikel er at belyse de konsekvenser, som introduktionen af nye medier kan have for biblioteksudviklingen i et historisk perspektiv. Biblioteker er op igennem historien løbende blevet udfordret af nye medier. Senest har den informationsteknologiske udvikling med digitaliseringen og udbredelsen af de såkaldte sociale medier skabt en diskussion om bogens og bibliotekernes overlevelse. Heller ikke den diskussion er i sin substans ny, idet tilsvarende overvejelser gjorde sig gaeldende, da fx nye lydbcerende medier gjorde deres entré $i$ de danske biblioteker i det 20. århundredes forste årtier. Mens telefonen umiddelbart blev accepteret som et nyttigt redskab, blev radioen som kommunikationsmiddel i folkebibliotekerne pure afvist blandt danske biblioteksfolk. Med udgangspunkt i nyere medieteorier fremsat af henholdsvis Enzensberger og Kittler skildres de receptionshistoriske aspekter ved introduktionen af to nye medier, henholdsvis telefonen og radioen, til de de danske folkebiblioteker, $i$ 1910'erne og 1920'erne.
\end{abstract}

Martin Dyrbye er lektor ved Det InformationsvidenskabeligeAkademi.md@iva.dk

\section{Indledning}

I den seneste Lov om biblioteksvirksomhed m.v. fra år 2000 er alle medier i princippet ligestillede, når der ses bort fra de såkaldte videogrammer, som folkebibliotekerne kan, men ikke er forpligtede til at anskaffe. I dag skelner borgerne ikke skarpt mellem de medier, som anvendes i dagligdagen, idet brugen af mediet er det afgørende. Bibliotekerne har gennem deres årtusinder lange udviklingshistorie tilpasset sig medieudviklingen med en større eller mindre forsinkelse.

I en dansk sammenhæng er det sammenlignet med fx USA og England relativt sent, at de såkaldte audio-visuelle medier begyndte at gøre sig gældende i forhold til biblioteksudviklingen. Faktisk var det først med den set med samtidens øjne epokegørende nye bibliotekslov fra 1964, at folkebibliotekerne kunne, men ikke var pligtige til, anskaffe fx grammofonplader og andre audio-visuelle hjælpemidler. Økonomien satte nogle begrænsninger, men også efterkrigstidens rationering og valutarestriktioner var medvirkende årsager til, at samtidens nye medier kun langsomt og gradvist nåede inden for folkebibliotekernes rækkevidde. Dertil kommer, at de trykte medier var en indgroet del af bibliotekernes naturlige udlåns- og formidlingsaktiviteter.

Med biblioteksloven fra år 2000 in mente vil befolkningen med rette kunne forvente, at nye medier i takt med deres fremkomst vil blive repræsenterede på bibliotekerne, for så vidt som de måtte kunne be- 
tragtes som videns- og eller kulturbærende i en eller anden forstand. Sådan har det imidlertid ikke været altid, som antydet ovenfor. En skepsis, ofte bundet i økonomiske overvejelser, over for nye medier er ikke noget nyt i bibliotekshistorien. Derfor er det netop i disse år, hvor nye medier til stadighed ser dagens lys, vigtigt at kaste et blik tilbage i tiden og undersøge, hvorledes nye medier de facto er blevet betragtet blandt biblioteksfolk, når de er dukket op i det danske biblioteksvæsen, her eksemplificeret ved to lydbærende medier, telefonen og radioen (Dyrbye et al., 2005)

Mens telefonen blandt biblioteksfolk ikke gav anledning til store protester eller egentlig frygt for dens konsekvenser i relation til folkebibliotekernes aktiviteter, forårsagede det nye radiomedie en diskussion om dets rolle og nytte.

Overvejelserne fra danske biblioteksfolk vedrørende konsekvenserne af det nye radiomedies udbredelse til et større publikum svarede på mange måder til dem, som deres udenlandske fagfæller gjorde sig i fx Tyskland og USA. I både amerikanske og tyske biblioteksfaglige tidsskrifter kan iagttages nogle af de samme tendenser som i Danmark i forhold til, hvorledes et nyt medie blev modtaget blandt biblioteksfolk i 1920'erne (The Library Journal, 1922; 1924; 1926; 1927; 1928; Public Libraries, 1922; 1923; 1925; 1926; 1928; Libraries, 1930; Bücherei und Bildungspflege, 1924; 1926; 1928).

Problemstillingen om et gammelt og afprøvet medies overlevelse ved fremkomsten af et nyt er velkendt, men også til stadig aktuel, jævnfør de overvejelser som den aktuelle digitaliseringsbølge giver anledning til (Carey \& Elton, 2010). Diskussionen i dag om den trykte bogs overlevelse i lyset af digitaliseringen og e-bogens udvikling er for så vidt ikke ny i dens grundsubstans. Spørgsmål, der uvilkårligt har rejst sig, når nye medier er begyndt at gøre sig gældende i forhold til bogtrykket, har fx været:

- Kan eller vil den trykte bog/bogtrykket overleve i fremtiden, når mediet udfordres af et nyt informationsbærende medie?

- Kan bibliotekerne overleve i lyset af nye mediers udvikling?
Medieudviklingen har også sat sig sine teoretiske spor, og i det følgende inddrages to tyske mediefilosoffer til belysning af de ovenfor rejste spørgsmål, som eksempler på, hvorledes problemstillingen kan anskues.

\section{Den medieteoretiske tilgang}

For 40 år siden fremkom Hans Magnus Enzensberger ud fra den i samtiden såkaldte kritisk-marxistiske teori med et såkaldt "Byggesæt til en medieteori”, en artikel som vandt stor udbredelse blandt litterater, sociologer og samtidens medieforskere. Artiklen er naturligvis bundet af sin tid, men fire årtier senere har dens hovedbudskab fortsat interesse, og Enzensbergers "byggesæts" enkelte dele kan udmærket transformeres om til en model, der kan hjælpe eftertiden med at forstå nogle af de mekanismer, der gør sig gældende, når nye medier bryder frem og udfordrer de eksisterende og velkendte. Det er siden blevet fremhævet, at Enzensberger anno 1970 tilhørte den gruppe blandt mediefilosoffer og medieforskere, der søgte at forstå medieudviklingen ud fra historiske og sociologiske årsagsforklaringer, mens de samtidig overså eller undervurderede de teknologiske faktorers betydning som forklaring på, hvorledes det kunne gå til, at fx nye elektroniske medier udvikler sig så hastigt, som det ofte er tilfældet, og vinder kolossal udbredelse kloden over. Samtidig hørte Enzensberger til blandt dem, som forholdt sig kritisk overfor mediefilosoffen McLuhans tanker om mediernes betydning for et samfund og tesen om, at mediet er budskabet. For Enzensberger var mediet i sig selv på ingen måde nok til at forklare dets udbredelse og i hans "Byggesæt" lægger han klar afstand til McLuhan.

I Enzensbergers sammenfatning af hans teoretiske overvejelser, byggestenene til hans byggesæt, om man vil, findes en slags model for, hvorledes medieudviklingen kan anskues og operationaliseres, idet han taler om en brug af medierne, som kan være henholdsvis repressiv og emancipatorisk. Denne synsvinkel opstilles skematisk og udfoldes herefter af Enzensberger i en længere redegørelse, men i den korte version, som i sin struktur er meget lig en model, opridses hvad der kan karakterisere en medieudvikling, nemlig: 


\begin{tabular}{|l|l|}
\hline "Repressiv mediebrug & Emancipatorisk mediebrug \\
\hline Centralt styret program & Decentraliserede programmer \\
En afsender, mange modtagere & Hver modtager er en potentiel afsender \\
Immobilisering af isolerede individer & Mobilisering af masserne \\
Passiv forbrugerholdning & Interaktion mellem deltagerne, feedback \\
Afpolitiseringsproces & Politisk læreproces \\
Produktion ved specialister & Kollektiv produktion \\
Kontrol ved besiddere eller bureaukrater" & Samfundsmæssig kontrol ved selvorganisation \\
(Enzensberger, 1971) & \\
\hline
\end{tabular}

Modsat Enzenberer har den ligeledes internationalt anerkendte tyske mediefilosof Friedrich Kittler markeret sig som fortaler for, at medieforskerne ikke nøjes med at betragte nye medier ud fra den historiske og sociologiske synsvinkel, altså fokuserer alene på konteksten mellem mediernes og samfundenes udvikling over tid, men i lige så høj grad fokuserer på, hvad det nye medie i sig selv er og rummer af muligheder, altså som objekt med et uhildet syn på dette som sådan. For at forstå et medie må dettes funktioner og opbygning dissekeres på dets egne præmisser, før det gøres til genstand for en teoretiseren og sociologisk-historisk udredning over et længere tidsforløb. Kittler er på ingen måde ahistorisk eller som Enzensberger upåvirket af den tyske historie i det 20. århundrede. På en helt særegen måde lader han den historiske dimension i medieudviklingen træde frem i sine skrifter. Flittigt citerer han samtidens egne iagttagere af medieudviklingen, og han demonstrerer, hvordan disse gennem tiderne har kunnet bidrage til forståelsen af de muligheder, som et nyt medie rummer på godt og ondt. På sin vis er det også Kittlers ærinde. Han ønsker, at gøre sin egen samtid opmærksom på betydningen af at fastholde og nedfælde de iagttagelser, som gøres, når et nyt medie udvikles over tid. I modsætning til Enzensberger har Kittler således ingen problemer med McLuhans påstand om, at mediet er budskabet, og at det som sådan har krav på en undersøgelse ud fra dets egne præmisser, herunder de teknologiske aspekter, som må indgå i forsøget på at forstå en given medieudvikling.

Modsat Enzensberger og dennes tilhængere kan Kittler godt opfattes som fortaler for det synspunkt, at et nyt medies indtog i verdensmediehistorien er revolutionerende og betyder en omvæltning i forhold til tidligere på en række områder, hvor verden så at sige ikke længere er den samme som forud for mediets entré på verdensarenaen (Kittler, 1986; 1999;
2010; Winthrop-Young \& Wutz, 1999; Durham, 2010)

En lignende tilsvarende tilgang kan iagttages hos den amerikanske sociolog Everett Rogers, som i værket Diffusion of Innovations (1962) i en teoretisk forståelsesramme beskæftigede sig med de konsekvenser, som innovationer har for menneskeheden og deres påvirkning af samfundsstrukturer o.l. Der er dog nuancer at spore i opfattelsen af, hvor dramatiske omvæltningerne er, når nye innovative tiltag introduceres. Kittler taler som nævnt om udviklingen som "revolutionerende", mens Rogers fremhæver, at udviklingen sker over tid. Som anført af Carey og Elton (2010) påpegede Rogers, at "the diffusion of an innovation is a process that takes place over time; it involves people who learn about the innovation in different ways and who operate in a social context into which the new technology or way of doing things may or may not fit easily." (Carey \& Elton, 2010, s. 19). Fælles for Enzensberger, Kittler og Rogers er deres fokus på innovationers konsekvenser for kulturer, mennesker og deres sociale relationer.

I det følgende benyttes såvel Enzensbergers som Kittlers tilgange til medieudviklingen med udgangspunkt i et par eksempler fra den danske medieudviklingshistorie. De belyser, hvorledes biblioteksfolk i deres samtid blev udfordret af nye medier, som kom til udefra, og som ikke på nogen måde lod sig standse i vækst og udbredelse uagtet, at mange mennesker samtidig bekymredes over udviklingen og nærede frygt for, at den trykte bog ikke ville overleve i fremtiden.

\section{Eksempler på modtagelsen af nye medier blandt biblioteksfolk}

Det 20. århundredes medieudvikling gik naturligvis heller ikke upåagtet hen for folkebibliotekernes ved- 
kommende, men de trykte medier havde en klar fortrinsstilling og et monopol frem til tiden efter 1945. De nye medier, der gjorde deres entré i tiden fra omkring 1. verdenskrig og op gennem mellemkrigstiden, som især spillede en rolle for folkebibliotekerne i Danmark var:

Telefonen

Radioen

Fotografier og film

Efter 2. verdenskrig fik flere andre lyd- og billedbærende medier en betydning for folkebiblioteksudviklingen frem til den nye, reviderede bibliotekslov i 1964, nemlig:

Mikrofilm

Grammofonplader og lignende lydoptagelsesmuligheder

Film

Radio

Fjernsyn

Malerier og grafik

Karakteristisk for disse nye medier var, at de enten blev opfattet som konkurrerende virksomhed, eller som et gode, der kunne bibringe folkebibliotekerne øgede midler og tiltrække flere, nye lånere. Samtidig var samtidens biblioteksfolk ikke blinde for de muligheder, som fx film, radio og senere fjernsynet rummede med henblik på at skaffe omtale og propagandere for folkebibliotekernes tilbud. Nogle af medierne fik en central rolle som nye udlånstilbud, mens andre alene blev opfattet som propagandaredskaber i formidlingsøjemed. Flere af de nye medier blev først mødt med skepsis grænsende til mistro og blev senere accepterede fuldt ud på linje med kerneydelsen, altså formidlingen af trykte materialer (Dyrbye et al., 2005).

\section{Telefonen}

I dag, hvor en mobiltelefon er næsten hver mands eje, tænker ingen over, at den klassiske telefon førhen og helt frem til sidste del af 1900-tallet var et omkostningstungt informationsteknologisk gode, som det ikke var beskåret for alle og enhver at anskaffe uden videre. I en biblioteksmæssig sammenhæng gjorde den fremtrædende danske folkebibliotekspioner Andreas Schack Steenberg danske bogsamlings- og biblioteksfolk opmærksom på, at telefonen havde en vigtig rolle at spille. I Bogsamlingsbladet, som var talerøret og organet for bogsamlingssagens, senere bibliotekssagens venner organiserede i foreningen Danmarks Folkebogsamlinger, skrev Steenberg i den faste rubrik Fra fremmede Lande om telefonens muligheder i biblioteksarbejdet:

"Telefonen i offentlige Biblioteker. Det er meget almindeligt i amerikanske Biblioteker, at der igennem Telefonen rettes Forespørgsler, ikke alene om Bøger, men ogsaa om andre Forhold, som man kan søge Oplysning om i Bibliotekets Læsesal. I det engelske Tidsskrift "Library" giver Bibliotekaren ved Cardiff offentlige Bibliotek Meddelelse om Telefonens Brug i engelske Biblioteker. Biblioteket i Cardiff besvarer saaledes telefoniske Forespørgsler angaaende Folks Bopæl, Togtider, Telegram-Coder m.m. Bibliotekaren er overbevist om, at Bibliotekernes Telefonkontor vil komme til at spille en stor Rolle og vil vise sig meget nyttig for Byens Beboere." (Bogsamlingsbladet, 1908, s. 5).

Som bekendt fik den engelske bibliotekar ret i sine betragtninger om telefonens nytte og værdi for folkebibliotekerne, men der gik imidlertid mange år, før den fik en større udbredelse i almindelighed pga. dens anskaffelsespris og de løbende driftsomkostninger. Hovedparten af lånerne havde ej heller telefon, og dermed blev dens værdi i relationen låner-bibliotek temmelig begrænset. Efter 2. verdenskrig fik flere og flere lånere råd til at anskaffe sig en telefon, hvilket også var tilfældet for folkebibliotekernes vedkommende. Imidlertid valgte 2 egentlige folkebiblioteker at anskaffe telefoner omkring 1 . verdenskrig.

I 1914 oprettedes de første to moderne centralbiblioteker i Danmark, nemlig i Holbæk og Vejle. Begge biblioteker havde telefoner. Den ihærdige bibliotekar og bibliotekspioner Aage Petersson fortalte begejstret læserne af Bogsamlingsbladet om centralbiblioteket i Holbæk og dets fortræffeligheder, deriblandt mulighederne for oprettelsen af en musikafdeling for "national og klassisk Musik" med omkring 200 bind noder, takket være en række gaver, og desuden kunne biblioteket ganske vist ikke ekspedere bøger "efter telefonisk Bestilling", men "Indmeldelser og Forespørgsler om en bestemt Bog eller et Emne sker derimod hyppigt pr. Telefon." En forudbestilling af bøger af "Oplysningslitteratur" kunne ske "pr. Telefon", og når en titel "indgaar i Biblioteket meddeles dette til Rekvirenten pr. Telefon eller Brevkort", og 
herefter var den reserveret til låneren 7 dage. (Bogsamlingsbladet, 1914, s. 119-120).

Mens det nye centralbibliotek i Holbæk ikke påkaldte sig den helt store opmærksomhed blandt samtidens bogsamlings- og biblioteksfolk, fik centralbiblioteket i Vejle langt større omtale i åbningsåret 1914. Dets nyudnævnte leder, cand.mag. Hvenegaard Lassen, havde ladet sig uddanne til bibliotekar i Amerika og nød derved stor anerkendelse. I forbindelse med centralbibliotekets åbning i Vejle benyttede Hvenegaard Lassen og bibliotekets bestyrelse lejligheden til at få arrangeret et bogsamlingsmøde i byen på Valdemarsdag, den 15. juni 1914. I rådhusets festsal mødte 200 mennesker op og havde lejlighed til at lytte til foredrag, arrangeret af biblioteket og Danmarks Folkebogsamlingers "Agitationsudvalg". Efter fællesangen "Vi fik ej under Tidernes Tryk" holdt 3 af samtidens mest fremtrædende bogsamlings- og bibliotekspionerer foredrag. Fra Statens Bogsamlingskomité mødte formanden op, Andreas Schack Steenberg, for at tale om "Bøger og Mennesker", mens Det Kongelige Bibliotek var repræsenteret ved overbibliotekar H. O. Lange, der talte om "Samvirke i Bibliotekssagen", og som repræsentant for folkeoplysningen og højskolebevægelsen mødte højskoleforstander Helge Hostrup, der talte om "Folkeoplysning og Selvarbejde."

Især Steenbergs foredrag er interessant for eftertiden med hensyn til hans betragtninger om ét af de nye kommunikationstiltag, som det nye centralbibliotek havde taget, men som i øvrigt ikke var ulig det, som også centralbiblioteket i Holbæk som før nævnt havde indført. I sit foredrag lovpriste Steenberg den nytiltrådte overbibliotekar for centralbiblioteket i Vejle og karakteriserede Hvenegaard Lassen som "en ung, ivrig og oplysningsbegejstret Mand, der efter en afsluttet videnskabelige Uddannelse ved Universitetet, har faaet en udmærket Uddannelse som Bibliotekar ved vort største Folkebibliotek, Københavns Kommunes Biblioteker. Hans Hjælp komme alle tilgode, der søger op paa Biblioteket". Men yderligere var der grund til, ifølge Steenberg, at fremhæve ét af Hvenegaard Lassens nye tiltag:

"Der hænger oppe i Biblioteket en Telefon. Gjennem den vil han kunne naa vidt omkring med sine Raad og Oplysninger om Bøger. Det er en fornøjelig Ting at tænke paa, at Telefontraaden, som hidtil har haft sin Hovedopgave i det praktiske Livs Tje- neste, nu ogsaa kan begynde at sprede Oplysning ud i vide Kredse.”(Bogsamlingsbladet, 1914, s. 65)

Disse ord om telefonen og dens muligheder blev udtalt 6 år efter Steenbergs første indlæg herom i Bogsamlingsbladet $\mathrm{i} 1908$.

Telefonen vandt i de følgende årtier indpas i de danske biblioteker og blev som antydet af Steenberg i 1914 et vigtigt praktisk redskab i oplysningsarbejdet. Efter 2. verdenskrig hæftede fx ledende landspolitikere sig ved betydningen af, at borgerne blot kunne kontakte det lokale folkebibliotek telefonisk for at få svar på spørgsmål og bestille bøger m.v. Både fra landspolitisk og lokalpolitisk side vandt folkebibliotekerne stor anerkendelse, og som sådan mødte disse efterhånden kommunaliserede oplysningsinstitutioner ikke nogen større politisk modstand. Netop betydningen af muligheden for telefonisk kontakt mellem borger og bibliotek blev således fremhævet af venstrepolitikeren Buhl, der i en biblioteksdebat om bibliotekslovens revision i 1950 fra Folketingets talerstol udtalte følgende:

"Jeg må have lov til med det samme at yde bibliotekernes service en lille kompliment. Bibliotekerne yder hjælpen glad og gerne. Jeg har ofte ringet til biblioteket i den købstad, der ligger nærmest mit hjem, og blot givet bibliotekaren et par tips, idet jeg har sagt: Jeg vil gerne udarbejde noget om det eller det. To dage efter har jeg fået en hel stabel bøger med mærker lagt ind der, hvor oplysningerne findes. Det er en service, som ikke ydes på noget som helst andet område."(Dyrbye et al., s. 161).

På det førnævnte bogsamlingsmøde i Vejle i 1914 var det som om, at også H. O. Lange fornemmede, at nye kommunikationsformer, som ikke nødvendigvis var baseret på skriftlighed, var på vej, omend han naturligvis ikke kunne forudsige den betydning kobberledninger, lyslederkabler og trådløs kommunikation ville få for spredningen af viden og dermed også for biblioteksvæsnet. H. O. Lange sammenlignede udviklingen af et offentligt biblioteksvæsen med udviklingen inden for andre "offentlige væsener" og anførte:

"Lad os tænke paa Udviklingen paa den materielle Oplysnings Omraade. Oprindelig hvade man ikke Gadebelysning eller elektrisk Lys i Husene. 
Ligsom hver sad ved sin private Lampe eller sit et Tællelys i sin Stude, saaledes førte han sin egen Gadebelysning med sig i Form af en Haandlygte, ja de fleste gik vel i Seng med Hønsene. Det var vistnok meget bekvemt for Stimænd og Røvere, der selvfølgelig ikke selv førte Lygte med sig: og det gik jo endelig op for Befolkningen, at Oplysningen er en fælles Sag, og man fik offentlig Gadebelysning. Ja, nu leverer Kommunen jo Belysning til os ind i Husene.

Oprindelig maatte hver enkelte, hjulpet af $\mathrm{Na}-$ boer og gode Venner, slukke en Ildebrand i sit Hus; men ogsaa paa dette Omraade opdagede man, at Samvirke var nødvendigt, og man indførte det kommunale Brandvæsen.

Det frie offentlige Bibliotek kan ogsaa ved Samvirke mellem alle Kræfter blive en aandelig Lysstation for alle Byernes Indbyggere.” (Bogsamlingsbladet, 1914, s. 68)

Netop som led i bestræbelserne på at udbygge folkebibliotekernes rolle som oplysningsinstitutioner foreslog Hvenegaard Lassen godt en halv snes år senere, i 1925, at der blev oprettet "et Centralkontor med Telefon, hvortil man fra Provinsen kunde henvende sig og faa oplyst, hvor Bøgerne findes. Han foreslog Nedsættelsen af et lille Udvalg om sagen." (Bogens Verden, 1925, s. 107-108)

Det er interessant, at telefonens udbredelse opfattes positivt blandt samtidens biblioteksfolk. I en Kittlersk forstand er eksemplet med til at belyse, hvorledes et medies udbredelse blev betragtet af dem, som stod i den aktuelle situation og skulle tage stilling til, hvorvidt det rummede muligheder for bibliotekerne eller ej i henseende til anskaffelsen af en telefon. Telefonen var revolutionerende ved dens fremkomst tilbage i 1870'erne, men nu 40-50 år senere var det ikke dens negative sider, som i samtiden blev fremhævet, men alene de økonomiske omkostninger, som var udgangspunkt for en kalkule om, hvorvidt dens indførelse kunne betale sig eller ej på længere sigt. Telefonen blev betragtet som en praktisk foranstaltning, der kunne lette arbejdet blandt bibliotekernes personale, og omvendt fik borgerne mulighed for en bedre service uden, at det gik ud over bogudlånet. Desuden kunne telefonen ikke regnes for at være en trussel mod bibliotekernes overlevelse, idet teknologien ikke kunne overflødiggøre hverken de trykte medier eller bibliotekspersonalet.
I en Enzensbergersk forstand må deres betragtninger kategoriseres som henhørende under "Emancipatorisk mediebrug". Brugen af mediet fandt sted decentralt, og det lokale perspektiv, altså borger - bibliotekar/bibliotek i lokalsamfundet fremhæves i de fundne kilder som væsentligt. Det er selvindlysende med netop telefonen, at modtageren af samtalen også er en potentiel afsender, og ligeledes at apparatet kunne medvirke til en "mobilisering af masserne" og samtidig give feedback gennem en interaktion. Her synes Enzensbergers betragtninger stadig at give mening, mens hans sidste tre punkter under "Emancipatorisk mediebrug" synes mere luftige. Talen om en "Politisk læreproces", "Kollektiv produktion" og "Samfundsmæssig kontrol ved selvorganisation" kan dog udmærket give en vis mening i lyset af de overvejelser, jf. ovenfor, som biblioteksfolk og en repræsentant for det politiske system gjorde sig, når talen falder på brugen af telefonen i en biblioteksmæssig kontekst.

\section{Radioen og folkebibliotekerne.}

I løbet af 1920erne vandt en ny slags åndelig lydstation også indpas i Danmark. Ganske vist kun til glæde for de få, entusiasterne, men fra politisk side blev man hurtigt klar over, at radioens gennembrud over den ganske verden efter 1 . verdenskrigs afslutning ville få vidtrækkende betydning for samfundsudviklingen. Det nye medies fremkomst betød oprettelsen af Statsradiofonien som forsøgsordning i 1925, hvor radiospredningen i realiteten blev monopoliseret og nationaliseret. Statsradiofonien blev gjort permanent i 1926. Enkelte meget fremsynede biblioteksfolk ytrede sig om det nye medies muligheder, men samtidig måtte de sande, at ny informationsteknologi og overvejelser om deres eventuelle nytte i en bibliotekssammenhæng ikke nødvendigvis havde en let gang på jorden i forhold til den gængse opfattelse af, at trykte medier var det bærende element i biblioteksarbejdet og udbredelsen af folkeoplysning. Samtidig kan det have spillet en rolle, at nye medier for bibliotekernes vedkommende kunne opfattes som farlige konkurrenter.

I 1920'erne blev radioen efterhånden meget udbredt, og konturerne af et egentligt nyt massemedie kunne anes ude i horisonten, og som på så mange andre områder med hensyn til udbredelsen af ny teknologi var amerikanerne også her at betragte som et foregangsland. Også amerikanske biblioteksfolk var begej- 
strede for radiomediets muligheder. I modsætning til radiofoni-udviklingen i Europa var det nye massemedie i Nordamerika ikke begrænset af en egentlig statslig regulering. Mange amerikanske biblioteker så fordelene i at udnytte radiospredningens muligheder for at formidle litteratur, viden, oplysning og kultur i videre forstand, end det ellers havde været muligt før radioens udbredelse. Der findes således flere eksempler på, at der dels blev oprettet egentlige radiofonistationer i de offentlige biblioteker på egne frekvenser, dels i samarbejde med eksterne samarbejdspartnere. Radioforedrag, radioteater, koncerttransmissioner og andre områder blev transmitteret og formidlet af bibliotekerne. Endvidere blev det også i flere tilfælde muligt at være tilhører til radiotransmissioner fra bibliotekernes kultursale, og dermed var publikum både en del af bibliotekets direkte formidling, dels medvirkende i radioens kulturformidling på en og samme tid.

Mens amerikanske biblioteksfolk begejstredes over radiomediets muligheder, var deres tyske kolleger $\mathrm{i}$ 1920 'erne mere skeptiske overfor radioens mulige skadevirkninger på folkebiblioteksbenyttelsen. Dette må for øvrigt ses i sammenhæng med tyske biblioteksfolks angst for, at bogen som medie var truet. Dog ikke som følge af den øgede radiospredning, men snarere på grund af den stærke udbredelse af det, som biblioteksfolk - ikke blot i Tyskland, men også i fx Danmark og mange andre lande - betragtede som underlødig litteratur. Tankegangen var, at bogen som medie ville gå til grunde, hvis ikke den dårlige litteratur blev bekæmpet. Ved radiomediets udbredelse, herunder oprettelsen af flere større radiofonistationer i fx Berlin og Køln, oplevede bibliotekerne en øget konkurrence, og bekymringen for, hvorvidt folk ville ophøre med at læse bøger og i stedet lytte til radio, kan spores blandt biblioteksfolk. Samtidig kunne de konstatere, at også radiomediet, i lighed med den trykte bog, muliggjorde udbredelsen af såkaldt underlødig kultur eller rendyrket underholdning. I Tyskland blev der ligefrem draget en parallel til ordet "idioti" ved at benytte et til lejligheden nyopfundet ord, "Radiotismus", om det nye medies muligheder for at virke fordummende på dets lyttere.

Både træk fra biblioteksudviklingen i USA og Tyskland kan iagttages i en dansk sammenhæng, hvor også danske biblioteksfolks modtagelse af det nye radiomedie prægedes enten af en optimistisk tro på dets uanede muligheder som et af mange redskaber i bibliotekernes kulturformidling, eller en dyb mistro og skepsis overfor dets påståede skadelige indflydelse på befolkningens dannelsesniveau. Med Kittlers tilgang in mente må viden om, hvorledes danske biblioteksfolk i deres egen selvforståelse modtog det nye medie, altså radioen, søges i samtidens kilder. Samtidig søges ved hjælp af Enzensbergers medieteoretiske overvejelser en forklaring på, hvorfor fx danske biblioteksfolk ikke på samme måde som fx amerikanerne ufortrødent tog radiomediet til sig og benyttede det som et blandt flere tiltag til at få både faste, men også nye lånere i tale.

I bibliotekstidsskriftet Bogens Verden, der efter samlingen af biblioteksvæsenets forskellige interesser ved dannelsen af Danmarks Biblioteksforening i 1919 fungerede som et fælles talerør for bibliotekssagen, tillod lærer Arne V. Frandsen sig i 1925 at ytre sig om "Radio paa Læsesalen". Indledningsvis konstaterede han:

"Vi lever i Radioens Tegn. Alt drejer sig om Radio, og alle taler om Radio. Vi spiser vore tørre Rugbrødsskorper og dito Ostegnallinger i Takt til Taffelmusik fra London, vi "synger" vore Børn i Søvn pr. Radio, og senere paa Aftenen jazzer vi med vore Bedste- eller Oldeforældre ligeledes til Højttalerens Toner, eller vi foretrækker, siddende i vore Lænestole, at høre sidste Nyt fra Paris, London, Liverpool, o.s.v. o.s.v.

Om Morgenen vækkes vi af Radiomandens Højttaler; i vore Tog har man anstillet Forsøg med Modtagelse af Radiomeldinger, Forsøg der vist er faldet ud til alles Tilfredshed - særlig vel Passagerernes."

Også strømmen af såkaldte "Radiokataloger", altså salgskataloger, var mærkbar ifølge Frandsen, som ligeledes havde bidt mærke i lånernes efterspørgsel efter bøger på "vort Bibliotek", hvor der var "Reserveringer i Snesevis af Radiobøger, saa Byens mest rolige Menneske, Bibliotekaren, er ved at fortvivle. Og han spørger sig selv, hvad dette skal ende med; alle vil jo læse om Radio.”

Den megen omtale af og interesse blandt lånerne for radiomediet ledte Frandsen hen på "den Erkendelse, at det Tidspunkt ikke er saa forfærdelig langt borte, da hans eget Bibliotek maa anskaffe sig et Radioapparat, og som i en Drøm ser han sig selv hver Aften paa Læsesalen omgivet af en lyttende Skare unge og 
gamle, medens Højttaleren meddeler de sidste Nyheder fra London eller Paris", og hans drømmesyn fortsætter:

"Saa indstiller han Apparatet paa en anden Bølgelængde, og det lyder: "Hallo! Hallo! Statens Bibliotekstilsyns Folkeviseaften!, og efter en kendt Overbibliotekar har givet et kort Rids af Folkevisernes Betydning, hører man Gengivelser af danske Folkeviser."

Mulighederne var ifølge Frandsen mange med henblik på udnyttelsen af radioen i biblioteksøjemed. Ved et evt. fælles indkøb af et apparat i samarbejde med andre biblioteker ville "et Radioapparat med Antenne, der tydeligt gengiver alle europæiske Stationer" kunne anskaffes for ca. $250 \mathrm{kr}$., hvilket set med samtidens øjne var et stort beløb, omregnet til 2011-priser svarende til godt $7.000 \mathrm{kr}$. Imidlertid ville investeringen tjene sig hjem, idet Frandsen mente, at radioen på læsesalen ville betyde et forøget antal besøgende. Set i lyset af konkurrencesituationen i forhold til samtidens fremadstormende billedmedie, altså fra biografteatrene, gav det også mening med det nye tiltag:

"Det er billigere at gaa paa Biblioteket for at faa Tiden til at gaa, maaske endda ved noget morsomt, end det er at gaa i Biografen, for paa Biblioteket er det gratis. Det er indlysende, at Tilstrømningen i Begyndelsen med et mildt Udtryk vil blive overvældende; men det bliver den ved alt nyt; snart vil der danne sig en fast Stok af Lyttere, men selvfølgelig vil ogsaa andre end denne komme, især unge Mennesker, som ellers vilde tilbringe Tiden paa Gaden eller i en eller anden Biograf; det sidste Sted er snart værre end det første."

Ifølge Frandsen ville det have en gavnlig effekt for biblioteket med indførelsen af radiolytning, idet de interesserede ville "føle sig hjemme paa Biblioteket", og tilføjede han: "er det ikke det, man skal? Skal man ikke ligesom hjemme kunne tage en Bog ned fra Hylden, sætte sig til Rette med denne i et lyst og lunt Lokale?"

For Frandsen var der ingen tvivl om, at "Radioen har sin Berettigelse paa Bibliotekets Læsesal", og den havde "foruden sin oplysende Mission ogsaa en moralsk", men sluttede han: "... hvem tør forsøge?".
De tanker og overvejelser, som Frandsen gjorde sig, vakte imidlertid stor opsigt og gav anledning til kritiske røster i Bogens Verden og endog også satiriske vers fremført i et digt i Aarhus Amtstidende. En Riedewaldt-Schøtt imødegik i et indlæg i Bogens Verden i kraftige vendinger Frandsens forslag og synspunkter. Ifølge Riedewaldt-Schøtt var der ikke i første omgang tale om et forsøg på "Bibliotekshumor", men derimod var det åbenbart Frandsens "alvorlige Mening at ville have Radio indført paa Læsesalen". Han frakendte på ingen måde "Betydningen af Læsning af Skønlitteratur som Hvile og Adspredelse for den trætte Hjerne - men med Hr. Frandsens Forslag er vi kommet ind paa en Opfattelse af Folkebibliotekernes Mission, der er ganske forfejlet." Det gamle forfægtede synspunkt om, at folkebiblioteker ikke skulle være et "Lejebibliotek" med alene romanlæsning for øje, fremførtes kraftfuldt, og RiedewaltSchøtt benyttede lejligheden til at gøre det synspunkt gældende, at folkebibliotekerne burde "øve en endnu skarpere Kritik end hidtil ved Anskaffelsen af Skønlitteratur." Dog underkendte han ikke, at det kunne være "heldigt, at mange unge Mennesker søger Læsesalen i Stedet for Gadelivet og Biografen", men tanken om hjemlig hygge forbundet med læsesalen afvistes kategorisk. Især Frandsens vending om, at læsesalsbenyttere skulle kunne "sætte sig til Rette" vakte harme, thi "det leder Tanken hen paa "Hjemmejakke", Piberøg og Toddyglas", hvilket lå langt fra Riedewaldt-Schøtt og i øvrigt også andre af hans samtids biblioteksfolks idealer om læsesalens formål:

"- den offentlige Læsesal er et Oplysningsbureau, en Studiehjælp, men ingen Varmestue. Og hvis jeg søger en Læsesal for at bruge Haandbøgerne, skal jeg meget have mig frabedt at blive forstyrret af en Radio-Højttaler."

Dertil kom så i øvrigt, at Riedewaldt-Schøtt i almindelighed nærede en mistro og skepsis overfor radioens "oplysende Mission" med "disse planløse Foredrag, der plejer Folks Dovenskab", som åbenbart modvirkede menneskers mulighed for at "lære at læse selv og arbejde med et Stof?". Konklusionen var ifølge Frandsens modstander klar. Han værgede sig ved at tro, at "noget Bibliotek for alvor vilde tænke paa at bruge Radioen som Lokkemad".

Også fra Bogens Verdens redaktion blev der taget forbehold overfor ideen om radio på læsesalen. Man gjorde udtrykkeligt opmærksom på, at "Indholdet af 
indsendte Artikler i dette som i alle andre Tilfælde staar for den paagældende Indsenders egen Regning, og at Optagelsen ikke er ensbetydende med en Tilslutning fra vor Side, selvom vi ikke udtrykkelig tager Afstand fra de fremsatte Tanker." Fra redaktionens side anførtes, at "vi baade i Skrift og Tale gentagne Gange har taget til Orde mod Bestræbelserne for at udvide Bibliotekernes Virksomhed til Felter, der ligger udenfor deres naturlige Omraade, og fremhævet Nødvendigheden af, at de koncentrerer Kræfterne om deres egentlige Opgaver, navnlig saa længe man endnu adskillige Steder ikke har Materiale nok til at bestride denne fyldestgørende."

For yderligere at imødegå Frandsens indlæg bragte Bogens Verden tre strofer fra et satirisk digt bragt i Aarhus Amtstidende, som åbenbart var kommet undervejs med forslaget om radio på læsesalen:

"I de gode gamle Dage var en Læsesal et Sted, hvor Folk gik ind og satte sig saa fredeligt og fandt en lille rar og morsom Bog at sysle med og læste længe, tyst og trygt og redeligt. Men den Slags er i Længden altfor kedeligt.

Nej, Folk i vore Dage maa med Tiden følge Trop og ej for dens Idéer miste Sansen.

Hvor dejligt paa en Læsesal at blive vækket op med Ordet: Nu begynder Vrikkedansen! midt i en svær Roman af Børge Janssen.

Hvorfor skal Folk paa Læsesalen spilde deres Tid med stadigvæk at terpe i Romaner?

Det vilde være dejligt efter fem Minutters "Slid" med Læsning af "Den sidste Mohikaner" at vækkes af "Yes, we have no Bananer!"

Selvom tanken om radiolytning på læsesalen blev kategorisk afvist, betød det ikke, at radiomediet i sig selv blev betragtet som uinteressant $i$ en bibliotekssammenhæng. En måned efter Frandsens indlæg, i juni 1925, beskæftigede læreren A. Ulrichsen, fra Helberg Skole på Als i Sønderjylland, sig med tanken om at inddrage radioen i biblioteksarbejdet. I et indlæg i Bogens Verden, "Radio og Biblioteksarbejdet", betegnede han radioen som den "nye Kulturfaktor", der nu var begyndt at gøre sig gældende, og han fortsatte indledningsvis:

"Det Stadium, da Radioamatørerne var en Række eksperimenterende unge Mennesker, der var "bidt af en gal Polytekniker", og da Radioapparaterne var Legetøj og Snurrepiberier, er for længst overstaaet. Nu hører en god Modtager næsten til Nutidsmenneskets Fornødenheder og Bekvemmeligheder."

Derfor var det vigtigt for "enhver, der arbejder i Oplysningens Tjeneste", at radioen nu var blevet "en ny Medarbejder, hvis umaadelige Betydning ikke lader sig overskue". Han var således ikke enig med Riedewalt-Schiøtts ytringer om, at radioens "oplysende Betydning" alene udgjordes af "planløse Foredrag, der plejer Folks Dovenskab", selvom han samtidig måtte medgive, at den danske radio havde lidt af børnesygdomme med "lidt Planløshed og lidt Kævl", men mediet kunne udmærket bruges "ej blot til Lyst". I Tyskland havde radioamatører således haft glæde af en "Mængde Foredrag af oplysende Art". Modstanden blandt fx biblioteksfolk mod radiomediet skyldtes ifølge Ulrichsen den traditionelle modsætning eller "Striden mellem det talte og det skrevne Ord" i Danmark. Der var ifølge Ulrichsen ingen grund til at forkaste radiomediet af den grund, og han henviste til, at endog en række forelæsninger fra "Universitetet i Paris" blev "broadcastet".

Ifølge Ulrichsen var radioen "et udmærket Agitationsmiddel til at "vække et Folk af Dvale". Som et godt dansk eksempel på, hvorledes radioen gjorde gavn i bibliotekssagens tjeneste, fremhævede han et radioforedrag i foråret 1925 om "Bøgers Brug" holdt af biblioteksagitatoren, pædagogen og konsulent i Statens Bibliotekstilsyn Jørgen Banke. Det var, anførte Ulrichsen, "fortrinlig holdt og udmærket udsendt, æggende og ildnende". Samtidig ville radioforedragene formentlig få en mere fremtrædende placering i Danmark efter at "en Mand som Magister Jens Rosenkjær har faaet sæde i Radioraadet." I den sammenhæng påpegede Ulrichsen fremsynet og strategisk tænkende, at:

"... enhver Ven af Folkeoplysningen og Folkeopdragelsen bør hjælpe til at føre Radioen ind i dette Spor, at det ikke skal gaa med denne Opfindelse som med Filmen; den kunde ogsaa blevet en udmærket Kulturspreder og Folkeopdrager, men den synes efter min Mening at blive ikke saa lidt misbrugt."

Han rejste herefter det spørgsmål, som til hver en tid må anses for relevant i medieudviklingen, nemlig 
hvordan bibliotekerne skulle "stille sig til denne nye Bevægelse?". Radioen var ifølge Ulrichsen kommet for at blive. Den kunne ikke "flot" afvises som "Gøgl og Legetøj", og radioen spildte ikke nødvendigvis folks tid, der ellers "kunde være brugt til at læse Bøger i". I stedet måtte radioen betragtes som "en Medarbejder, der styrer mod samme Maal", altså en hjælper i folkeoplysningens tjeneste.

Tanken om en radiohøjtaler på læsesalen afviste Ulrichsen på linje med andre biblioteksfolk: "I et Læseværelse bør der være Ro", men til gengæld foreslog han noget helt banebrydende, nemlig indretningen af "offentlige Radiolokaler" på linje med "Læseværelser" (læs: læsesale). Disse to lokaler, altså "Læseværelset" og "Radiolokalet", kunne ifølge Ulrichsen placeres inden for samme lokalitet, så "det talte og skrevne Ord arbejde Haand i Haand ved at lægge dem sammen og lade dem arbejde sammen, i Stedet for at overlade Radioens Udvikling til Klubberne", men samtidig erkendte Ulrichsen resignerende, at radioen "blev et Led mere i den Skjoldborgske "Kulturhal i "Ideale Magter". - Men Tidens Løsen er jo "Arbejdets Deling" og Specialisering, saa det bliver vel ikke den Vej, man gaar."

Når formidlingen af radio i realiteten ikke lod sig gøre i et samvirke med bibliotekerne, måtte sidstnævnte til gengæld udnytte befolkningens interesse for det nye medie ved at udlåne "alt, hvad der skrives om Radio". Dvs. ikke alene "Fagtidsskrifter og Fagbøger for Selvbyggere og Konstruktører", men også radioprogrammer fra alle radiostationer, der kunne aflyttes i Danmark, burde være tilgængelige på læsesalene, alene af den grund, at det ikke var "ingen helt billig Historie for Privatmand at holde den samlede Radiopresse, men dertil har vi Bibliotekerne."

Desuden foreslog Ulrichsen, at bibliotekerne formidlede "Tekstbøger", dvs. lærebøger til sprogundervisning gennem selvstudium, idet kendskabet til fremmedsprog, især engelsk og fransk, blev øget gennem radiomediet, der blev betragtet som et "aldeles fortrinligt Hjælpemiddel" til sprogundervisning. Desuden ville det være hensigtsmæssigt, hvis tekstforlæg til udsendelserne, fx skuespil, blev tilgængeliggjort på bibliotekerne, for: "Saa kan man følge med i Bogen Linie for Linie, efter som Oplæsningen eller Skuespillet skrider frem, og kan, hvis man sidder alene i sin Stue, uden at forstyrre de Optrædende i London, Paris eller Berlin gentage Replikkerne højt efter dem for rigtig at indøve Mundstillingen", og tilføjede den lærenemme Ulrichsen: "Paa den Maade har undertegnede, hvem det er lykkedes at fremskaffe Programmer i god Tid og derefter har laant Tekstbøger forskellige Steder, særlig fra Statsbiblioteket i Aarhus, kunnet følge med i en Række Oplæsninger og Skuespil." Med andre ord: det var altså områder, hvor "Radio og Bibliotek" kunne "arbejde Haand i Haand, og der skal nok vise sig flere."

I sine afsluttende bemærkninger noterede Ulrichsen sig, hvorledes radioen kunne virke som brobygger i den gamle strid om det levende ord og den trykte bogs rolle for folkeoplysningen". Formidlingen af radiomediet på bibliotekerne kunne betyde, at der ville "melde sig en Skare af videbegærlige, hvis interesse for dette eller hint var blevet vakt gennem et Radioforedrag", thi "dette er vel Sandheden i Striden mellem "det levende Ord" og Bogstaven: Vækkelsen og den første Belæring kommer gennem det mundtlige Ord, men den egentlige Tilegnelse, Fæstelse og Uddybelse sker ved Bogens Hjælp." (Bogens Verden, 1925 , s. $36-37$; s. $60-61$; s. 80-82)

\section{Perspektivering}

Det er, set i lyset af medieudviklingen i dag, interessant at iagttage, hvorledes radioen som et nyt medie i 1920'erne blev opfattet af fx biblioteksfolk, ikke alene i Danmark, men også i andre lande, her eksemplificeret ved inddragelse af eksempler fra henholdsvis Tyskland og Amerika.

Mens telefonen ikke kunne opfattes som en trussel mod den trykte bog - tryksager i det hele taget - forholdt det sig anderledes med radioen, da den i løbet af 1920'erne vandt stadig større indpas i en række landes mediekultur. Den fik en stor udbredelse blandt dem, som fik betegnelsen "lyttere", helt tilsvarende de klassiske "læsere". I en medieteoretisk sammenhæng kan Kittlers fokusering på mediet i sig selv og dets teknologiske muligheder med en næsten McLuhan'sk tro på, at mediet er budskabet, iagttages i den danske bibliotekshistorie.

Samtidig kan også Enzensbergers tilgang bidrage til at forklare, hvorfor folkebibliotekerne i Danmark ikke, som det var tilfældet flere steder i USA, umiddelbart tog radiomediet til sig, da det begyndte at vinde mere almen udbredelse i løbet af 1920'erne. Mens der i USA faktisk var tale om, at folkebibliote- 
kerne takket være det, som Enzensberger benævnte emancipatorisk mediebrug, kunne udnytte radiomediets muligheder i formidlingsøjemed, gjaldt det stik modsatte i 1920'ernes danske mediebillede, hvor en såkaldt repressiv mediebrug i Enzensbergers forstand kom til at gøre sig gældende med Statsradiofoniens oprettelse i 1925, og dermed etableringen af en mediemonopolisering, der ikke gjorde det muligt for folkebibliotekerne at udnytte radioen som deres egen selvstændige og uafhængige ny formidlingskanal.

\section{Referencer}

Bogens Verden 1925, s. 36-37; s. 60-61; s. 80-82; s. 107-108.

Bogsamlingsbladet, 3. årg., maj 1908, s. 5; 9. årg., august-september 1914, nr. 5-6. s. 65 \& s. 68.

Bücherei und Bildungspflege, årg. 1924; 1926; 1928

Carey, John \& Elton, Martin CJ (2010). When Media Are New. Understanding the Dynamics of New Media Adoption and Use. Ann Arbor: The University of Michigan Press and The University of Michigan Library.

Dyrbye, Martin et al. (2005). Det stcerke folkebibliotek. København: Danmarks Biblioteksforening.

Enzensberger, Hans Magnus (1971). Byggesæt til en medieteori. Trykt i Vindrosen 3/71. 18. årg., s. 2-
26. København: Gyldendal. [Artiklen, oversat af Ole Klitgård, udkom oprindeligt på tysk, "Baukasten zu einer Theorie der Medien”, trykt i: Kursbuch nr. 20, 1970].

Kittler, Friedrich (1986). Grammophon, Film. Berlin: Brinkmann \& Bose, 1986.

Kittler, Friedrich (2010). Optical Media: Berlin Lectures 1999. Translated by Anthony Enns. Cambridge: Polity.

Libraries, årg. 1930.

The Library Journal, årg. 1922; 1924; 1926; 1927; 1928.

Peters, John Durham (1999). Introduction: Fridrich Kittler's Light Shows. I: Friedrich Kittler: Optical Media: Berlin Lectures. Translated by Anthony Enns. Cambridge: Polity, 2010. s. 1-17.

Public Libraries, årg 1922; 1923; 1925; 1926; 1928.

Winthrop-Young, Geoffrey \& Wutz, Michael (1999). Translators' Introduction xi-xxxiii i: Kittler, Friedrich, A.: Gramophone, Film, and Typewriter. Translated, with an Introduction, by Geoffrey Winthrop-Young and Michael Wutz. Stanford, California: Stanford University Press. 